\title{
Effect of lotus leaf on the quality characteristics and antioxidant properties of bread
}

\author{
La-Young Park* \\ Department of Food Science and Technology, Catholic University of Daegu, Gyeongsan 38430, Korea
}

연잎 첨가가 제빵 특성 및 항산화 활성에 미치는 영향

\author{
박나영* \\ 대구가톨릭대학교 식품공학전공
}

\begin{abstract}
This study was carried out to investigate the quality characteristics and antioxidative activity of bread containing lotus leaf powder (in ratios of $0,1,2$, and $3 \%$ of the total flour). The $\mathrm{pH}$ of dough and bread were decreased as the concentration of lotus leaf powder increased. The volume of dough during fermentation did not show significant difference between $1 \%$ lotus leaf powder containing dough and control. The weight of bread increased by addition of lotus leaf powder. The volume, specific volume and baking loss rate of the bread decreased as lotus leaf powder levels increased. Redness and yellowness of the inner crumb were decreased by the addition of lotus leaf powder, but lightness was increased. 2,2-diphenyl-1-picrylhydrazyl-radical scavenging activity and total polyphenol contents were increased significantly as the concentration of lotus leaf powder increased. The overall acceptability of bread containing $1 \%$ lotus leaf powder showed no significant difference compared with control. The result exhibited that adding the lotus leaf powder into the bread increased antioxidant activity, and the highest quality improvement was obtained by incorporating $1 \%(w / w)$ lotus leaf powder into the bread formula.
\end{abstract}

Key words : DPPH radical scavenging activity, lotus leaf powder, bread property, quality characteristics

\section{서 론}

최근 경제 성장과 더불어 식생활의 고급화, 간편화를 지 향하는 경향이 나타나면서, 가공식품을 단순한 먹거리로만 여기지 않고 건강 증진 기능을 갖춘 기능성 식품의 형태로 이용하려는 경향이 두드러지고 있다. 이에 제빵 업계에서 도 이러한 소비자의 건강 지향적 트랜드에 부응하기 위해 제품 개발에 있어 다양한 성분과 기능을 가진 천연 소재를 활용하여 건강 및 기능성을 향상시키고자 하는 노력이 활발 하게 진행되고 있다.

연(Nelumbo nucifera)은 수생식물 중 부엽식물에 속하는

*Corresponding author. E-mail : violet74@cu.ac.kr

Phone : 82-53-850-3140, Fax : 82-53-850-3140

Received 12 December 2016; Revised 23 February 2017; Accepted 13 March 2017.

Copyright (c) The Korean Society of Food Preservation. All rights reserved.
쌍떡잎식물로써 꽃은 관상용과 차제(茶劑)로 이용되어 왔 으며, 잎과 뿌리는 식용하여 왔다(1). 연잎은 하엽이라 하여 맛이 쓰고 성질이 유하며 예로부터 출혈성 위 궤양이나 위염, 치질, 출혈, 설사, 두통, 어지럼증, 토혈, 산후 어혈치료 야뇨증, 해독작용에 쓰며, 민간치료제로도 사용되어 왔다 (2). 연잎에서 분리된 생리활성 성분으로는 nelumboside, nuciferine, coclaurine 등의 alkaloid류, gallic acid와 methyl gallate 등의 aromatic acid류 및 quercetin, isoquercitrin, hyperoside, rutin, kaempferol 등의 flavonoid류가 있다 $(3,4)$. 연잎을 이용한 생리활성에 관한 연구로는 연잎의 지질 저하 효과 $(1,5)$, 연잎 추출물의 항산화 효과(6)와 항균효과(7), 연근, 연잎, 조릿대의 대사성 질환 완화 작용(8) 등이 있으 며, 식품에 이용한 연구로는 연꽃과 연잎으로 제조한 연엽 주(9), 연잎차(10), 연잎 절편(11), 연잎 가루를 첨가한 설기 떡(12,13), 어묵(14), 국수(15) 등에 대한 연구가 있으나, 연 잎 분말을 이용한 가공식품 개발의 예는 아직 드문 실정이 다. 다양한 생리활성을 가진 연잎의 이용분야 확대 및 다양 
한 식빵제품 개발을 위한 기초자료를 제공하고자 연잎분말 을 밀가루 대신 일정비율로 첨가하여 식빵을 제조하면서 연잎분말이 제빵 특성 및 항산화 활성에 미치는 영향을 검토하고자 하였다.

\section{재료 및 방법}

\section{실험재료}

연잎 분말은 국산 연잎을 건조시킨 후 분말화 한 것을 그린바이오팜(Seoul, Korea)에서 구입하였으며, 연잎 $100 \%$ 조성 제품을 사용하였다. 식빵 조제에 필요한 밀가루는 강 력분(Cheiljedang, Seoul, Korea), 이스트는 고당용 생이스트 (Jenico, Food Co., Ltd., Seoul, Korea), 이스트푸드는 S-500(Puratos, Belgium), 설탕은 백설탕(Samyang Co., Seoul, Korea), 소금은 정제염(Daehan Salt Manufacture, Youngam, Korea), 탈지분유(Seoul Milk, Seoul, Korea), 마가 린(Grand-300, Lottefood, Cheonan, Korea)을 사용하였다 항 산화 활성 및 폴리페놀 함량 측정 등의 실험에 사용된 모든 시약 및 용매는 Sigma-Aldrich Co.(St. Louis, MO, USA)에서 구입한 분석급 시약을 사용하였다.

\section{일반성분 분석}

연잎 분말의 일반 성분분석은 식품공전의 분석방법(16) 에 따라 수행하였다. 수분은 $105^{\circ} \mathrm{C}$ 건조법으로 측정하였고, $550^{\circ} \mathrm{C}$ 회화로에서 직접 회화법, Soxhlet법, Kjeldahl 질소 정량법을 이용하여 조회분, 조지방, 조단백질 함량을 측정 하였다.

\section{연잎의 생리활성 측정}

연잎의 생리활성을 측정하기 위해 연잎 분말과 $95 \%$ 에탄 올을 1:9의 비율로 혼합하여 상온에서 $150 \mathrm{rpm}$ 으로 진탕시 키면서 24시간 동안 추출후 여과(Whatman No. 1, SigmaAldrich, Maidstone, England)하여 회전진공농축기(WB 2000, Heidolph, Schwabach, Germany)로 농축하였다. 연잎 농축물은 동결건조하여 분말화시켰으며 이를 적정 농도로 재용해하여 사용하였다.

총 폴리페놀 함량은 Folin-Denis (17)의 방법에 따라 측정 하였다. 시료 $1 \mathrm{~mL}$ 를 취하여 $0.2 \mathrm{~N}$ Folin-Ciocalteu 시약 $1 \mathrm{~mL}$ 를 가하여 혼합하여 실온에서 3분간 반응시킨 후, 이 반응용액에 $7.5 \% \mathrm{Na}_{2} \mathrm{CO}_{3} 1 \mathrm{~mL}$ 를 첨가하여 진탕한 후 1 시 간 실온에서 방치하여 $765 \mathrm{~nm}$ 에서 흡광도를 측정하였다. 측정된 흡광도는 tannic acid를 이용하여 작성된 검량선으 로 총 폴리페놀 함량을 계산하였다.

$\mathrm{DPPH}$ radical 소거능은 Blois(18)의 방법으로 측정하였 다. 각 시료 용액 $0.2 \mathrm{~mL}$ 를 취하여 $0.4 \mathrm{mM}$ 2,2-diphenyl1-picrylhydrazyl(DPPH) 용액 $0.8 \mathrm{~mL}$ 를 가하여 10 초 동안
진탕한 후 10 분 동안 방치하고 $525 \mathrm{~nm}$ 에서 흡광도를 측정 하였으며 다음의 계산식, DPPH radical scavenging ability $(\%)=100-[(\mathrm{OD}$ of sample/OD of control $) \times 100]$ 에 의하여 활 성을 산출하였다.

아질산염 소거능은 Kato 등(19)의 방법에 따라 각 추출물 $1 \mathrm{~mL}$ 에 $1 \mathrm{mM} \mathrm{NaNO}_{2}$ 용액 $1 \mathrm{~mL}$ 를 가하고 $0.1 \mathrm{~N} \mathrm{HCl}$ 을 가하여 총 부피를 $10 \mathrm{~mL}$ 로 하였다. 이 용액을 $37^{\circ} \mathrm{C}$ 에서 1 시간 반응시킨 후 $1 \mathrm{~mL}$ 를 취하여 $2 \%$ 초산용액 $4 \mathrm{~mL}$ 와 $30 \%$ 초산용액으로 용해한 Griess reagent $(1 \%$ sulfanilic acid: $1 \%$ naphthylamine=1:1) $0.4 \mathrm{~mL}$ 를 가한 후 실온에서 15 분간 방치하여 $520 \mathrm{~nm}$ 에서 흡광도를 측정하였으며 다음 의 계산식, nitrite scavenging activity $(\%)=100-[(\mathrm{OD}$ of sample/OD of control $) \times 100]$ 에 의하여 산출하였다.

\section{식빵의 제조}

연잎 가루는 밀가루 양에 대해서 $1 \%, 2 \%$ 및 $3 \%(\mathrm{w} / \mathrm{w})$ 를 첨가하였고, 그 외 첨가물의 조성 및 제조 방법은 $\mathrm{Bae}$ 등(20) 의 방법에 따라 실시하였으며, 배합비는 Table 1 에서 보는 바와 같다. 제빵 공정은 직접반죽법에 준해서 반죽은 쇼트 닝을 제외한 전 재료를 동시에 넣고 수화한 다음, clean up 단계가 되면 쇼트닝을 첨가하여 반죽하였다. 이 반죽을 온도 $38^{\circ} \mathrm{C}$, 상대습도 $85 \%$ 인 발효실에서 60 분간 1차 발효시 킨 다음 가스를 빼고 성형하여 온도 $38^{\circ} \mathrm{C}$, 상대습도 $85 \%$ 인 발효실에서 40 분 동안 2 차 발효시키고 상단 $180^{\circ} \mathrm{C}$, 하단 $210^{\circ} \mathrm{C}$ 온도로 예열된 전기오븐에서 구운 후 실온에서 1 시간 식힌 다음 실험에 사용하였다.

Table 1. Ingredient composition of breads added with lotus leaf powder at different concentration

\begin{tabular}{ccccc}
\hline Ingredient & Control & LLP-1 $^{1)}$ & LLP-2 & LLP-3 \\
\hline Wheat flour & 1,000 & 990 & 980 & 970 \\
Water & 620 & 620 & 620 & 620 \\
Sugar & 80 & 80 & 80 & 80 \\
Salt & 18 & 18 & 18 & 18 \\
Yeast & 35 & 35 & 35 & 35 \\
Shortening & 80 & 80 & 80 & 80 \\
Skim milk powder & 30 & 30 & 30 & 30 \\
Lotus leaf powder & 0 & 10 & 20 & 30 \\
\hline
\end{tabular}

${ }^{1)}$ LLP-1, Added with lotus leaf powder at 1\%; LLP-2, Added with lotus leaf powder at $2 \%$; LLP-3, Added with lotus leaf powder at $3 \%$.

\section{반죽 발효능}

반죽의 발효능은 반죽을 끝낸 시료 $10 \mathrm{~g}$ 을 채취하여 실험 조작이 용이하도록 덧가루를 바르고 $100 \mathrm{~mL}$ 메스실린더에 넣어 식빵 제조용 반죽과 함께 1 차 발효하여 발효가 끝난 직후 둥글게 올라온 반죽의 윗부분을 편평하게 하여 부피를 
측정하여 그 평균치를 사용하였다(21).

\section{무게, 부피, 굽기 손실률 및 용적비 측정}

식빵의 무게와 부피는 제품을 1 시간 동안 실온에서 방치 한 후 무게를 측정하였고, 부피는 종실을 이용한 종자치환 법으로 부피를 측정하였다(22). 식빵의 굽기 손실율(\%)은 [(반죽의 중량 $(\mathrm{g})-$ 제품의 중량 $(\mathrm{g}) /$ 반죽의 중량 $(\mathrm{g})] \times 100$ 의 계 산식에 의하여 측정하였으며, 용적비는 빵 $1 \mathrm{~g}$ 이 차지하는 부피 $(\mathrm{mL})$ 로 나타내었다.

\section{$\mathrm{pH}$ 및 산도 측정}

식빵과 반죽의 $\mathrm{pH}$ 및 적정산도는 시료 $10 \mathrm{~g}$ 에 $90 \mathrm{~mL}$ 증류수를 가하여 균일하게 혼합시킨 다음 homogenizer (Nissei, Nihonseiki kaisha LTD., Tokyo, Japan)로 5분간 균질 시킨 후 pH meter(Orion 410A, Orion Research Inc, Boston, $\mathrm{MA}, \mathrm{USA}$ )로 측정하였다. 적정산도는 혼합액 $10 \mathrm{~mL}$ 를 채 취하여 phenolphthalein용액 2-3방울을 떨어뜨린 후 $0.1 \mathrm{~N}$ $\mathrm{NaOH}$ 로 중화 적정하여 소비량 $(\mathrm{mL})$ 을 lactic acid \%로 환산 하였다(23).

\section{색도 측정}

반죽과 식빵 표면과 내부의 색도 측정은 Hunter color difference meter(CR 200, Minolta, Tokyo, Japan)를 사용하여 백색도(L, lightness), 적색도(a, redness), 황색도(b, yellowness) 값을 각각 5 회 측정하여 그 평균값으로 나타내었다. 식빵의 표면 색도는 식빵의 측면 껍질 부분을, 내부 색도는 슬라이 스 한 식빵의 내부 부분의 색도를 측정하였다. 이때 표준색 은 $\mathrm{Y}=94.95, \mathrm{x}=0.3132, \mathrm{y}=0.3203$ 였다.

\section{Texture 측정}

식빵의 조직감은 rheometer(Compac-100, Sun Scientific Co., Tokyo, Japan)로 분석하였으며, 식빵의 중앙부위를 $4 \times 4 \times 2 \mathrm{~cm}^{3}$ 으로 절단한 후 직경이 $25 \mathrm{~mm}$ 인 원통형 plunger 를 이용하였다. Rheometer의 측정조건은 최대하중 $2 \mathrm{~kg}$, table speed $60 \mathrm{~mm} / \mathrm{min}$, distance는 $50 \%$ 의 조건으로 측정하 였다. 모든 시료는 10 반복 측정하여 평균값 \pm 표준편차로 나타내었다.

\section{전자공여능 및 총 폴리페놀 함량 측정}

식빵의 생리활성 측정을 위한 시료 처리는 $\mathrm{Yu}$ 등(24)의 방법으로 실시하였다. 즉, 식빵의 동결건조물 $6 \mathrm{~g}$ 에 $40 \mathrm{~mL}$ 의 메탄올을 첨가하여 12 시간 추출한 후 $3,000 \mathrm{rpm}$ 에서
10 분간 원심분리한 후 상등액을 취하여 사용하였다. 총 폴 리페놀 함량 및 전자공여능 측정은 각각 Folin-Denis(17), Blois(18)의 방법으로 실시하였다.

관능검사

식빵의 관능검사는 대구가톨릭대학교 식품가공학과 학 생 25 명을 대상으로 본 연구의 취지와 관능검사와 관련된 교육을 실시한 후 관능검사를 실시하였다. 갓 구워낸 식빵 을 실온에서 2 시간 동안 방냉시킨 후 시료의 중간부분을 일정한 크기 $(5 \times 5 \times 0.8 \mathrm{~cm})$ 로 잘라 각각을 흰 접시에 담아 물과 함께 실온에서 동시에 제공하였다. 맛, 색, 풍미, 종합 적 기호도를 5점 채점법(27)으로 평가하였으며, 아주 좋다 는 5점, 보통이다는 3점, 아주 나쁘다는 1점으로 평가하였 다.

\section{통계처리}

통계처리는 SPSS 통계 package program(Statistical package social science, version 12.0, SPSS Inc., Chicago, $\mathrm{IL}, \mathrm{USA})$ 을 이용하여 분산분석(ANOVA)을 실시하였고, 처 리군간의 유의성은 Duncan's multiple range test로 검정하여 분석 평가하였다.

\section{결과 및 고찰}

\section{연잎 분말의 일반성분 및 생리활성}

연잎 분말의 일반성분을 조사한 결과는 Table 2 에서 보는 바와 같다. 연잎분말의 수분함량은 $2.61 \%$, 조회분은 $10.68 \%$, 조지방은 $3.40 \%$, 조단백질은 $22.31 \%$ 로 나타났다. Lee 등(25)이 일광 건조한 연잎의 일반성분을 분석한 결과, 회분, 지질, 단백질의 함량은 각각 $9.3 \mathrm{~g} / 100 \mathrm{~g}, 1.0 \mathrm{~g} / 100$ $\mathrm{g}, 16.9 \mathrm{~g} / 100 \mathrm{~g}$ 으로 본 실험에서 사용한 연잎 분말의 조단백 질, 조지방, 조회분 함량이 높았다. 일반적으로 조단백질의 경우 재배지역, 수확시기, 품종, 비료, 재배의 유두 등에 따라 차이가 있다고 알려져 있다(26). 본 실험의 성분 함량 이 Lee 등(25)의 실험 결과와 상이한 이유도 재배지역 및 수확 시기 차이에 의한 것으로 판단이 된다. 연잎 분말을 $95 \%$ 에탄올로 추출하여 총 폴리페놀 함량과 $\mathrm{DPPH}$ 라디칼 소거능을 조사한 결과, $1 \%(\mathrm{w} / \mathrm{v})$ 농도에서 총 폴리페놀은 $270.85 \mathrm{\mu g}$ tannic acid $/ \mathrm{mL}$ 였으며, $0.1 \%(\mathrm{w} / \mathrm{v})$ 농도에서 $\mathrm{DPPH}$ 라디칼 소거능은 $90.1 \%$, 아질산염 소거능은 $36.3 \%$ 를 나타내어, 연잎 분말을 이용하여 식빵을 제조하였을 때,

Table 2. Proximate composition and antioxidative activity of lotus leaf powder

\begin{tabular}{cccccccc}
\hline Sample & $\begin{array}{c}\text { Moisture } \\
(\%)\end{array}$ & $\begin{array}{c}\text { Crude ash } \\
(\%)\end{array}$ & $\begin{array}{c}\text { Crude fat } \\
(\%)\end{array}$ & $\begin{array}{c}\text { Crude protein } \\
(\%)\end{array}$ & $\begin{array}{c}\text { Total polyphenol } \\
(\mu \mathrm{g} / \mathrm{mL})\end{array}$ & $\begin{array}{c}\text { DPPH radical } \\
\text { scavenging activity } \\
(\%)\end{array}$ & $\begin{array}{c}\text { Nitrite scavenging } \\
\text { activity } \\
(\%)\end{array}$ \\
\hline Lotus leaf powder & $2.61 \pm 0.13$ & $10.68 \pm 0.05$ & $3.40 \pm 1.40$ & $22.31 \pm 0.25$ & $270.85 \pm 7.14$ & $90.08 \pm 0.10$ & $36.30 \pm 1.16$ \\
\hline
\end{tabular}


연잎의 항산화 활성 효과도 기대해 볼 수 있을 것으로 판단 된다.

\section{$\mathrm{pH}$ 및 산도}

연잎 분말을 첨가한 빵 반죽과 식빵의 $\mathrm{pH}$ 는 Table 3 에 나타내었다. 대조구와 연잎 분말 $1 \%, 2 \%$ 및 $3 \%$ (LLP-1, LLP-2 및 LLP-3)를 첨가한 반죽의 $\mathrm{pH}$ 는 각각 5.16, 5.13, $5.10,5.08$ 로 연잎 분말 첨가량이 증가할수록 $\mathrm{pH}$ 는 감소하 였으며, 대조구와 LLP-1은 서로 유의적 차이를 보이지 않았 으나, $2 \%$ 이상 첨가한 반죽은 대조구에 비해 유의적으로 낮았다 $(\mathrm{p}<0.05)$. 연잎 분말 첨가 식빵의 $\mathrm{pH}$ 가 대조구보다 낮은 것은 연잎에 함유된 malic acid, succinic acid 및 acetic $\mathrm{acid}$ 와 같은 유기산(27)이 영향을 미쳤기 때문인 것으로 판단된다. 식빵의 $\mathrm{pH}$ 는 반죽보다 $\mathrm{pH}$ 가 다소 높았으나, 반 죽의 $\mathrm{pH}$ 변화 경향과 유사하게 연잎 분말 첨가량이 증가할 수록 식빵의 $\mathrm{pH}$ 도 감소하였다. 반죽의 산도는 0.030 $0.040 \%$ 의 범위를 나타내었고, 식빵의 산도는 $0.025-0.030 \%$ 를 나타내어, 연잎 분말 첨가량이 증가할수록 산도도 높았다.

반죽의 발효능과 굽기 손실률

연잎 분말 첨가에 따른 밀가루 반죽의 발효능과 식빵의 굽기 손실률을 측정한 결과는 Table 4 와 같다. 대조구 반죽

Table 3. $\mathrm{pH}$ and titratable acidity of doughs and breads with different concentrations of lotus leaf powder

\begin{tabular}{cccc}
\hline Sample & Treatment $^{1)}$ & $\mathrm{pH}$ & Titratable acidity \\
\hline \multirow{4}{*}{ Dough } & Control & $5.16 \pm 0.02^{\mathrm{a} 2)}$ & $0.030 \pm 0.000^{\mathrm{c}}$ \\
& LLP-1 & $5.13 \pm 0.01^{\mathrm{a}}$ & $0.030 \pm 0.001^{\mathrm{c}}$ \\
& LLP-2 & $5.10 \pm 0.01^{\mathrm{b}}$ & $0.036 \pm 0.000^{\mathrm{b}}$ \\
& LLP-3 & $5.08 \pm 0.00^{\mathrm{b}}$ & $0.040 \pm 0.001^{\mathrm{a}}$ \\
\hline \multirow{5}{*}{ Bread } & Control & $5.31 \pm 0.01^{\mathrm{a}}$ & $0.025 \pm 0.001^{\mathrm{c}}$ \\
& LLP-1 & $5.29 \pm 0.03^{\mathrm{a}}$ & $0.026 \pm 0.000^{\mathrm{c}}$ \\
& LLP-2 & $5.24 \pm 0.01^{\mathrm{b}}$ & $0.029 \pm 0.000^{\mathrm{b}}$ \\
& LLP-3 & $5.19 \pm 0.01^{\mathrm{c}}$ & $0.030 \pm 0.000^{\mathrm{a}}$ \\
\hline
\end{tabular}

${ }^{1)}$ LLP-1, Added with lotus leaf powder at 1\%; LLP-2, Added with lotus leaf powder at $2 \%$; LLP-3, Added with lotus leaf powder at $3 \%$.

${ }^{2)}$ Values are mean \pm SD, and means with different superscripts in the same column are significantly different at $\mathrm{p}<0.05$ by Duncan's multiple range test.
의 발효 후 팽창된 부피는 $31.33 \mathrm{~mL}$ 이었으나, LLP-1의 부피 는 $30.83 \mathrm{~mL}$ 로 대조구에 비해 낮게 나타났으나 유의적인 차이는 나타나지 않은 반면, LLP-2와 LLP-3은 각각 30.33, $29.67 \mathrm{~mL}$ 로 대조구에 비해서 발효 후 부피 팽창 정도는 유의적으로 낮았다. 이는 한라봉 분말(28) 및 버찌분말(29) 을 첨가한 식빵에서도 부재료의 첨가량이 증가할수록 반죽 의 발효능이 감소하여 본 실험의 결과와 유사한 경향을 나타내었다. 연잎 분말 첨가 반죽의 발효능이 감소하는 것 은 연잎분말 첨가량이 증가할수록 글루텐의 함량 비율이 감소하기 때문인 것으로 판단된다. 연잎 분말 첨가 식빵의 굽기 손실률은 $11.39-11.57 \%$ 로 대조구 $(11.82 \%)$ 에 비해 낮 았으며, 연잎 분말 첨가량이 증가할수록 굽기 손실율은 낮 은 경향을 나타내었다. 이는 한라봉(28) 분말, 우엉분말(30) 을 첨가한 식빵의 결과와도 일치하였다. Hong과 $\operatorname{Shin}(31)$ 에 의하면 굽기 손실률은 굽는 과정 중 열에 의한 휘발성 물질 의 휘발과 수분의 증발 등의 영향을 받는다고 보고하였고, $\mathrm{Bae}$ 등(32)은 감잎 가루 첨가량이 증가함에 따라 식빵의 굽기 손실률이 낮아지는 것은 감잎가루의 높은 수분 보유력 때문이라고 보고하고 있다.

빵의 무게, 부피 및 비용적

일반적으로 식빵의 부피는 품질평가의 주요 지표이다. 보편적으로 소비자들은 큰 부피의 제품을 선호하며, 제조 과정 중 제품의 중량과 부피의 감소는 제품의 선호도 측면 에서 바람직하지 못하다(33). 연잎 분말을 첨가한 식빵의 무게, 부피 및 용적비는 Table 4에 나타내었다. 대조구의 무게는 $476.17 \mathrm{~g}$ 이었으며, LLP-1은 $477.50 \mathrm{~g}$, LLP-2와 LLP-3은 각각 $476.83 \mathrm{~g}, 478.50 \mathrm{~g}$ 으로 연잎 분말 첨가량이 증가할수록 무게는 증가하는 경향을 나타내었다. 대조구의 부피는 $2,075 \mathrm{~mL}$ 을 나타내었고, 연잎 분말 첨가한 식빵은 2,053.33-2,068.33 mL의 범위를 나타내어 연잎 분말 첨가에 의해 부피는 감소하였으며, 연잎 분말 첨가량이 증가할수 록 부피도 감소하는 경향을 나타내었다. 이는 첨가물의 혼 합비율이 증가함에 따른 반죽내 밀가루 단백질의 함량이 감소되어 부피는 감소하였고(34,35), 연잎 분말에 함유된 식이섬유의 보수력에 의해 빵의 무게가 증가된 것으로 판단 된다(36-38). Yook 등(39)도 식이섬유 첨가에 의하여 식빵

Table 4. Effect of lotus leaf powder addition on dough volume after first fermentation and baking loss after bread baking

\begin{tabular}{cccccc}
\hline Treatment $\left.{ }^{1}\right)$ & Dough volume $(\mathrm{mL})$ & Baking loss $(\%)$ & $\begin{array}{c}\text { Loaf weight } \\
(\mathrm{g})\end{array}$ & $\begin{array}{c}\text { Loaf volume } \\
(\mathrm{mL})\end{array}$ & $\begin{array}{c}\text { Specific loaf volume } \\
(\mathrm{mL} / \mathrm{g})\end{array}$ \\
\hline Control & $31.33 \pm 0.58^{\mathrm{a} 2)}$ & $11.82 \pm 0.22^{\mathrm{a}}$ & $476.17 \pm 1.17^{\mathrm{b}}$ & $2,075.00 \pm 8.94^{\mathrm{a}}$ & $4.36 \pm 0.02^{\mathrm{a}}$ \\
LLP-1 & $30.83 \pm 0.29^{\mathrm{a}}$ & $11.57 \pm 0.37^{\mathrm{ab}}$ & $477.50 \pm 1.97^{\mathrm{ab}}$ & $2,068.33 \pm 5.16^{\mathrm{a}}$ & $4.33 \pm 0.04^{\mathrm{b}}$ \\
LLP-2 & $30.33 \pm 0.58^{\mathrm{ab}}$ & $11.51 \pm 0.22^{\mathrm{ab}}$ & $477.83 \pm 1.17^{\mathrm{ab}}$ & $2,058.67 \pm 6.35^{\mathrm{b}}$ & $4.31 \pm 0.01^{\mathrm{b}}$ \\
LLP-3 & $29.67 \pm 0.58^{\mathrm{b}}$ & $11.39 \pm 0.35^{\mathrm{b}}$ & $478.50 \pm 1.87^{\mathrm{a}}$ & $2,053.33 \pm 2.58^{\mathrm{b}}$ & $4.29 \pm 0.02^{\mathrm{c}}$ \\
\hline
\end{tabular}

\footnotetext{
${ }^{1)}$ LLP-1, Added with lotus leaf powder at 1\%; LLP-2, Added with lotus leaf powder at 2\%; LLP-3, Added with lotus leaf powder at $3 \%$.

${ }^{2)}$ Values are mean $\pm \mathrm{SD}$, and means with different superscripts in the same column are significantly different at $\mathrm{p}<0.05$ by Duncan's multiple range test.
} 
의 무게는 증가하였고, 부피는 감소한다고 보고하였다. 용 적비도 대조구가 $4.36 \mathrm{~mL} / \mathrm{g}$ 으로 가장 높았고, 연잎 분말 첨가구는 대조구보다 유의적으로 낮았으며 $(\mathrm{p}<0.05)$, 연잎 분말 첨가량이 증가할수록 용적비는 감소하였다.

\section{반죽 및 절단면 관찰}

연인 분말 첨가량을 달리하여 제조한 반죽과 식빵의 절 단면 및 외형은 Fig. 1에 나타내었다. 대조구와 LLP-1은 외형적 크기의 차이가 뚜렷하지 않는 반면 LLP-2와 LLP-2 는 외형적 크기의 차이를 보였으며, 식빵 내부의 기공도 연잎 분말 첨가량이 증가할수록 불규칙 적이며, 크기가 작 고 조밀 기공을 다수 관찰할 수 있었다. 연잎 분말을 첨가한 반죽의 색상 및 식빵 내부의 색상은 연잎 분말 첨가량이 증가할수록 어두우면서 진한 녹색을 나타내었다.
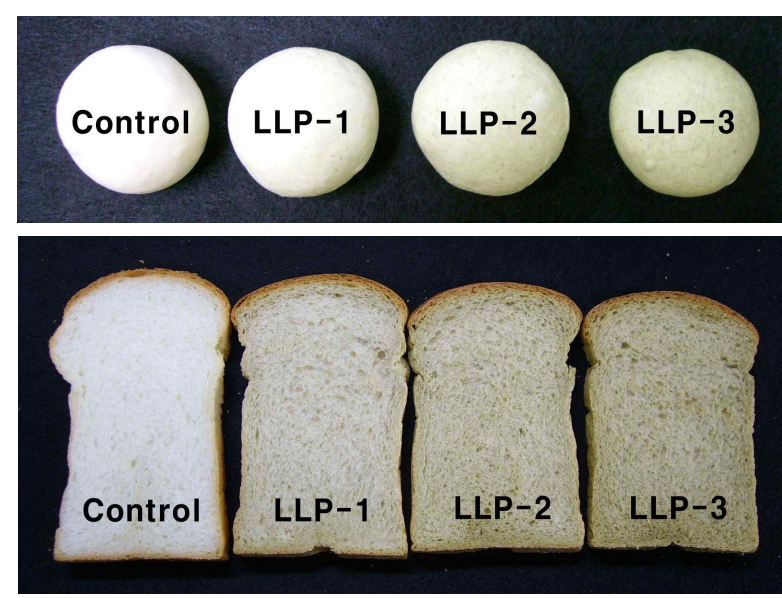

Fig. 1. Photograph of dough (up) and bread (down) with different concentration of lotus leaf powder.

LLP-1, Added with lotus leaf powder at 1\%; LLP-2, Added with lotus leaf powder at $2 \%$; LLP-3, Added with lotus leaf powder at $3 \%$.

반죽과 식빵의 색차

연잎 분말을 첨가한 반죽과 식빵의 색차는 Table 5에 나타내었다. 반죽의 명도를 나타내는 $\mathrm{L}$ 값은 대조구가 79.97, LLP-1, LLP-2 및 LLP-3은 각각 70.86, 66.48, 60.12로 연잎 분말 첨가량이 증가할수록 유의적으로 감소하였고, 적색도를 나타내는 a 값은 대조구가 -1.93 , 연잎 분말 첨가 구는 -5.04-4.33으로 연잎 분말 첨가량이 증가할수록 감소 하였다. 반죽의 b 값(황색도)은 대조구가 15.18 로 가장 낮았 으며, LLP-3은 1.83 으로 가장 높았다. 식빵 표면과 내부의 $\mathrm{L}$ 값도 대조구가 가장 높았으며, 연잎 분말 첨가량이 증가 할수록 유의적으로 $\mathrm{L}$ 값은 감소하였다. 빵 표면의 $\mathrm{a}$ 값과 $\mathrm{b}$ 값은 대조구가 가장 높았으며, 연잎 분말 첨가량이 증가할 수록 감소하였으나 빵 내부의 $\mathrm{a}$ 값과 $\mathrm{b}$ 값은 대조구가 가장 낮았으며 연잎 분말 첨가량이 증가할수록 높았다. 반죽과 식빵 색의 변화는 연잎 분말 고유색에 의한 영향으로, 가시 적으로도 연잎 분말 첨가량이 증가함에 따라 반죽과 식빵의
색이 짙어지는 경향을 나타내었다.

Table 5. Color values of doughs and breads with different concentrations of lotus leaf powder

\begin{tabular}{ccccc}
\hline Sample & Treatment $^{1)}$ & L & $\mathrm{a}$ & $\mathrm{b}$ \\
\hline \multirow{4}{*}{ Dough } & Control & $79.97 \pm 0.99^{\mathrm{a} 22}$ & $-1.93 \pm 0.04^{\mathrm{a}}$ & $15.18 \pm 0.23^{\mathrm{c}}$ \\
& LLP-1 & $70.86 \pm 0.75^{\mathrm{b}}$ & $-4.33 \pm 0.05^{\mathrm{b}}$ & $17.42 \pm 0.26^{\mathrm{b}}$ \\
& LLP-2 & $66.48 \pm 1.04^{\mathrm{c}}$ & $-4.72 \pm 0.09^{\mathrm{c}}$ & $17.59 \pm 0.04^{\mathrm{b}}$ \\
& LLP-3 & $60.12 \pm 0.24^{\mathrm{d}}$ & $-5.04 \pm 0.05^{\mathrm{d}}$ & $18.53 \pm 0.08^{\mathrm{a}}$ \\
\hline \multirow{4}{*}{ Top } & Control & $69.69 \pm 0.04^{\mathrm{a}}$ & $3.13 \pm 0.20^{\mathrm{a}}$ & $19.77 \pm 0.70^{\mathrm{a}}$ \\
crust & LLP-1 & $65.13 \pm 0.38^{\mathrm{b}}$ & $2.45 \pm 0.10^{\mathrm{ab}}$ & $19.25 \pm 0.32^{\mathrm{a}}$ \\
& LLP-2 & $62.44 \pm 0.20^{\mathrm{c}}$ & $1.86 \pm 0.07^{\mathrm{bc}}$ & $18.11 \pm 0.22^{\mathrm{b}}$ \\
& LLP-3 & $60.05 \pm 0.40^{\mathrm{d}}$ & $1.42 \pm 0.06^{\mathrm{b}}$ & $17.57 \pm 0.44^{\mathrm{b}}$ \\
\hline \multirow{4}{*}{ Bread } & Control & $68.53 \pm 0.42^{\mathrm{a}}$ & $-1.80 \pm 0.21^{\mathrm{b}}$ & $8.03 \pm 0.19^{\mathrm{d}}$ \\
& LLP-1 & $64.17 \pm 1.07^{\mathrm{b}}$ & $-1.98 \pm 0.06^{\mathrm{b}}$ & $12.86 \pm 0.48^{\mathrm{c}}$ \\
Internal & LLP-2 & $61.85 \pm 0.59^{\mathrm{c}}$ & $-1.76 \pm 0.12^{\mathrm{ab}}$ & $13.74 \pm 0.40^{\mathrm{b}}$ \\
& LLP-3 & $58.55 \pm 0.64^{\mathrm{d}}$ & $-1.58 \pm 0.28^{\mathrm{a}}$ & $14.46 \pm 0.45^{\mathrm{a}}$ \\
\hline
\end{tabular}

${ }^{11}$ LLP-1, Added with lotus leaf powder at $1 \%$; LLP-2, Added with lotus leaf powder at $2 \%$; LLP-3, Added with lotus leaf powder at $3 \%$.

${ }^{2)}$ Values are mean $\pm \mathrm{SD}$, and means with different superscripts in the same column for each sample are significantly different at $p<0.05$ by Duncan's multiple range test.

식빵의 조직감

연잎 분말을 첨가한 식빵의 조직감은 Table 6에 나타내었 다. 경도는 대조구가 $44.08 \mathrm{~g} / \mathrm{cm}^{2}$ 로 가장 낮았으며, LLP-1, LLP-2 및 LLP-3은 각각 $48.38 \mathrm{~g} / \mathrm{cm}^{2}, 54.59 \mathrm{~g} / \mathrm{cm}^{2}$ 및 62.46 $\mathrm{g} / \mathrm{cm}^{2}$ 로 대조구보다 높았으며, 연잎 분말 첨가량이 증가할 수록 경도도 높았다. 빵의 경도에 미치는 요인으로는 빵의 수분함량, 기공의 형성 정도, 부피 등이 있는데 기공이 잘 형성된 빵일수록 부피가 크고 부드러움이 증가하여 경도가 저하된다고 알려져 있다(33). 본 실험에서의 경도의 증가는 연잎 첨가에 의해 빵의 부피가 감소하게 되고, 기공이 작아 지고 기공의 밀집도가 높아졌기 때문인 것으로 판단되며 비용적이 가장 작았던 LLP-3의 경도가 가장 높았다. 응집성 과 씹힘성, 탄력성도 대조구에 비해 연잎분말 첨가 식빵이

Table 6. Textural characteristics of bread crumb with different concentration of lotus leaf powder

\begin{tabular}{ccccc}
\hline Treatment $^{1)}$ & $\begin{array}{c}\text { Hardness } \\
\left(\mathrm{g} / \mathrm{cm}^{2}\right)\end{array}$ & $\begin{array}{c}\text { Cohesiveness } \\
(\%)\end{array}$ & $\begin{array}{c}\text { Springiness } \\
(\%)\end{array}$ & $\begin{array}{c}\text { Chewiness } \\
(\mathrm{g})\end{array}$ \\
\hline Control & $\left.44.08 \pm 6.05^{\mathrm{d} 2}\right)$ & $99.75 \pm 4.56^{\mathrm{b}}$ & $97.72 \pm 2.85^{\mathrm{b}}$ & $81.84 \pm 9.85^{\mathrm{d}}$ \\
LLP-1 & $48.39 \pm 4.51^{\mathrm{c}}$ & $97.08 \pm 8.09^{\mathrm{b}}$ & $99.56 \pm 2.67^{\mathrm{ab}}$ & $93.47 \pm 6.84^{\mathrm{c}}$ \\
LLP-2 & $54.59 \pm 4.91^{\mathrm{b}}$ & $100.24 \pm 2.06^{\mathrm{ab}}$ & $99.87 \pm 2.33^{\mathrm{a}}$ & $108.75 \pm 9.49^{\mathrm{b}}$ \\
LLP-3 & $62.46 \pm 7.79^{\mathrm{a}}$ & $104.09 \pm 5.53^{\mathrm{a}}$ & $100.33 \pm 2.54^{\mathrm{a}}$ & $120.63 \pm 9.17^{\mathrm{a}}$ \\
\hline
\end{tabular}

${ }^{1)}$ LLP-1, Added with lotus leaf powder at 1\%; LLP-2, Added with lotus leaf powder at $2 \%$; LLP-3, Added with lotus leaf powder at $3 \%$.

${ }^{2)}$ Values are mean $\pm \mathrm{SD}$, and means with different superscripts in the same column are significantly different at $\mathrm{p}<0.05$ by Duncan's multiple range test. 
높았으며, 연잎 분말 첨가량에 비례하여 증가하는 경향을 나타내었다.

식빵의 DPPH라디칼 소거능 및 총 폴리페놀 함량 연잎 분말을 첨가한 식빵의 DPPH 라디칼 소거능과 총 폴리페놀 함량을 조사한 결과는 Table 8 에 나타내었다. 대 조구의 $\mathrm{DPPH}$ 라디칼 소거능은 $9.26 \%$ 였으며, 연잎 분말 $1 \%$ 첨가구는 $17.08 \%$ 로 대조구에 비해 높게 나타나 연잎 분말 첨가에 의해 $\mathrm{DPPH}$ 라디칼 소거능이 유의적으로 증가 하였다(p<0.05). 또한 LLP-2, LLP-3도 각각 $33.08 \%, 40.13 \%$ 를 나타내어 연잎 분말 첨가 농도에 비례하여 $\mathrm{DPPH}$ 라디칼 소거능도 유의적으로 증가하는 경향을 나타내었다( $\mathrm{p}<0.05)$. 총 폴리페놀 함량도 연잎 분말 첨가구가 615.01-885.13 tannic acid $\mu \mathrm{g} / \mathrm{mL}$ 을 나타내어 대조구(472.20 tannic acid $\mu \mathrm{g} / \mathrm{mL}$ )에 비해 높았으며, 연잎 분말 첨가량이 증가할수록 식빵의 총 폴리페놀 함량도 유의적으로 증가하였다 $(\mathrm{p}<0.05)$. 연잎 분말 첨가 식빵의 $\mathrm{DPPH}$ 라디칼 소거능의 증가는 연잎에 함유된 다양한 페놀성 물질 $(3,4,40)$ 에 기인 한 것으로 판단된다. 아로니아 첨가 식빵(41), 버찌 식빵(29) 및 어성초 첨가식빵(42)에도 각각의 부재료 첨가에 의해서 $\mathrm{DPPH}$ 라디칼 소거능이 유의적으로 증가한다고 하였고, 이는 부재료에 함유된 총 폴리페놀에 의한 것이라고 보고하 였다. 식빵 제조시 연잎 분말의 첨가는 연잎 자체가 가진 영양 성분 및 섬유질의 보충 외에도 총 폴리페놀 성분과 항산화 활성의 증진에도 기여할 것으로 판단된다.

Table 7. DPPH radical scavenging and total phenol contents of breads with different concentration of lotus leaf powder

\begin{tabular}{ccc}
\hline Treatment $^{1)}$ & DPPH radical scavenging (\%) & Total phenol contents $(\mu \mathrm{g} / \mathrm{mL})$ \\
\hline Control & $9.26 \pm 0.19^{\mathrm{d} 2)}$ & $472.20 \pm 14.13^{\mathrm{d}}$ \\
LLP-1 & $17.08 \pm 0.29^{\mathrm{c}}$ & $615.01 \pm 21.80^{\mathrm{c}}$ \\
LLP-2 & $33.08 \pm 0.18^{\mathrm{b}}$ & $766.59 \pm 22.81^{\mathrm{b}}$ \\
LLP-3 & $40.13 \pm 0.08^{\mathrm{a}}$ & $885.13 \pm 39.91^{\mathrm{a}}$ \\
\hline
\end{tabular}

${ }^{1}$ LLP-1, Added with lotus leaf powder at 1\%; LLP-2, Added with lotus leaf powder at $2 \%$; LLP-3, Added with lotus leaf powder at $3 \%$.

${ }^{2)}$ Values are mean $\pm \mathrm{SD}$, and means with different superscripts in the same column are significantly different at $\mathrm{p}<0.05$ by Duncan's multiple range test.
관능평가

연잎 분말을 첨가한 식빵의 관능검사 결과는 Table 9에 나타내었다. 맛은 대조구가 3.67로 가장 높은 평가를 받았 으며, 연잎 분말 첨가구는 2.92-3.56으로 대조구보다 유의 적으로 낮았다 $(\mathrm{p}<0.05)$. 특히 연잎분말 $3 \%$ 첨가구의 경우 2.92 로 가장 낮았는데 이는 연잎 특유의 풀맛과 신맛이 관능 적으로 영향을 주었기 때문인 것으로 판단된다. 풍미는 연 잎 분말 첨가량에 따른 유의적 차이는 나타나지 않았으나 $(\mathrm{p}<0.05)$, 연잎 분말 첨가량이 증가할수록 감소하는 경향을 나타내었다. 색의 경우, 대조구가 3.12 로 가장 낮은 반면 연잎 분말 $3 \%$ 첨가구가 3.68 로 가장 높게 나타나 흰색의 식빵보다는 유색의 식빵을 선호하는 것으로 나타났다. 이 는 소비자들이 건강 및 기호도를 고려한 다양한 빵 제품에 노출의 기회가 많아져, 유색빵에 대한 거부감이 없어졌으 며, 시중의 유색빵에 첨가되는 재료들이 건강에 효과가 있 을 것이라는 기대에 기인된 결과라고 생각된다. 조직감은 연잎 분말 첨가로 인해, 또한 첨가량 증가로 인해 기호도가 감소하는 경향을 나타내었는데 이는 연잎 분말 첨가에 의한 부피 및 비용적의 감소로 인한 경도의 증가와 관련이 있을 것으로 판단된다. 종합적 기호도는 대조구가 3.64로 가장 높았으며, 다음은 연잎 분말 $1 \%$ 첨가구(3.56)로 나타났으 나, 두 처리구간의 유의적인 차이는 나타나지 않았다 $(\mathrm{p}<0.05)$. 본 실험의 결과 연잎 분말 $3 \%$ 첨가구는 $\mathrm{DPPH}$ 라디칼 소거능, 총 폴리페놀 함량 및 기타 영양적 특성은 처리구 중에서 가장 우수하였으나, 색을 제외한 모든 관능 적 특성에서 기호도가 낮게 나타나 식빵 제조시 첨가량으로 는 적당하지 않은 것으로 판단되었다.

\section{요 약}

기능성 제빵 소재로써 연잎의 이용 가능성을 검토하기 위해 연잎 분말을 1,2 및 $3 \%$ 를 첨가하여 식빵을 제조하면 서 제빵 특성 및 빵의 품질특성을 조사하였다. 연잎 분말의 조회분, 조지방 및 조단백질 함량은 각각 $10.68,3.40$ 및 $22.31 \%$ 로 나타났으며, 연잎 분말 $95 \%$ 에탄올 추출물 $1 \%(\mathrm{w} / \mathrm{v})$ 농도에서 총 폴리페놀 함량은 $270.85 \mu \mathrm{g} / \mathrm{mL}$ 였으 며, $0.1 \%(\mathrm{w} / \mathrm{v})$ 농도에서 $\mathrm{DPPH}$ 라디칼 소거능은 $90.1 \%$ 를

Table 8. Sensory evaluation of breads with different concentrations of lotus leaf powder

\begin{tabular}{cccccc}
\hline Treatment $^{1)}$ & Taste & Color & Flavor & Texture & Overall acceptability \\
\hline Control & $3.67 \pm 0.75^{\mathrm{a} 2)}$ & $3.12 \pm 1.01^{\mathrm{b}}$ & $3.11 \pm 0.60^{\mathrm{a}}$ & $3.52 \pm 0.51^{\mathrm{a}}$ & $3.64 \pm 0.57^{\mathrm{a}}$ \\
LLP-1 & $3.56 \pm 0.71^{\mathrm{ab}}$ & $3.36 \pm 0.86^{\mathrm{ab}}$ & $3.22 \pm 0.67^{\mathrm{a}}$ & $3.44 \pm 0.58^{\mathrm{ab}}$ & $3.56 \pm 0.77^{\mathrm{a}}$ \\
LLP-2 & $3.20 \pm 0.65^{\mathrm{bc}}$ & $3.64 \pm 0.76^{\mathrm{a}}$ & $3.11 \pm 0.60^{\mathrm{a}}$ & $3.04 \pm 0.98^{\mathrm{b}}$ & $3.00 \pm 0.87^{\mathrm{b}}$ \\
LLP-3 & $2.92 \pm 0.86^{\mathrm{c}}$ & $3.68 \pm 0.80^{\mathrm{a}}$ & $2.89 \pm 0.78^{\mathrm{a}}$ & $2.56 \pm 1.00^{\mathrm{c}}$ & $2.84 \pm 0.75^{\mathrm{b}}$ \\
\hline
\end{tabular}

\footnotetext{
${ }^{1)}$ LLP-1, Added with lotus leaf powder at 1\%; LLP-2, Added with lotus leaf powder at 2\%; LLP-3, Added with lotus leaf powder at $3 \%$.

${ }^{2)}$ Values are mean $\pm S D$, and means with different superscripts in the same column are significantly different at $p<0.05$ by Duncan's multiple range test.
} 
나타내었다. 연잎 분말을 첨가한 식빵 반죽과 식빵의 $\mathrm{pH}$ 는 연 잎 분말 첨가량이 증가할수록 감소하였으며, 산도는 증 가하였다. 반죽의 부패 팽창도는 LLP-1과 대조구는 유의적 인 차이는 나타나지 않았다 $(\mathrm{p}<0.05)$. 연잎 분말 첨가 식빵의 굽기 손실률은 대조구에 비해 낮았으며, 식빵의 무게는 연 잎 분말 첨가량이 증가할수록 증가하였고, 부피는 감소하 였다. 식빵의 경도는 대조구가 가장 낮았으며 연잎 분말 첨가량이 증가할수록 경도도 높았다. 연잎 분말 첨가 식빵 의 $\mathrm{DPPH}$ 라디칼 소거능과 총 폴리페놀 함량은 각각 $17.08-40.13 \%$ 와 $615.01-885.13 \mathrm{\mu g} / \mathrm{mL}$ 의 범위를 나타내어 대조구에 $(9.26 \%$ 및 $472.20 \mu \mathrm{g} / \mathrm{mL})$ 에 비해 높았으며, 연잎 분말 첨가량이 증가할수록 식빵의 DPPH 라디칼 소거능 및 총 폴리페놀 함량도 유의적으로 증가하였다( $\mathrm{p}<0.05)$. 연 잎 분말을 첨가한 식빵의 종합적 기호도는 대조구가 3.64 로 가장 높았으며, 다음은 LLP-1(3.56)으로 나타났으나, 두 시 료간의 유의적인 차이는 나타나지 않았다 $(\mathrm{p}<0.05)$. 식빵의 기능적 특성과 관능적 특성을 고려하였을 때, 연잎 분말은 $1 \%$ 첨가하였을 때가 가장 적당하다고 판단되며, 최대 $2 \%$ 를 넘지 않은 것이 바람직할 것으로 사료된다.

\section{감사의 글}

이 논문은 2015도 대구가톨릭대학교 교내연구비 지원에 의한 것입니다. 지원에 감사드립니다.

\section{References}

1. Kim SB, Rho SB, Rhyu DY, Kim DW (2005) Effect of Nelumbo nucifera leaves on hyperlpidemic and atherosclerotic bio F1B hamster. Kor J Pharmacogn, 36, 229-234

2. Kong MH, Yeo SH, Choi JH, Choi HS, Jeong ST (2011) Characteristics of the Yakju fermented with differentlyprocessed lotus leaves. J East Asian Soc Dietary Life, 21, 911-917

3. Cho EJ, Yokozawa T, Rhyu DY, Kim SC, Shibahara N, Park JC (2003) Study on the inhibitory effects of Korean medicinal plants and their main compounds on the 1,1-diphenyl-2-picrylhydrazyl radical. Phytomedicine, $10,544-551$

4. Kashiwada Y, Aoshima A, Ikeshiro Y, Chen YP, Furukawa $\mathrm{H}$, Itoigawa $\mathrm{M}$, Fujioka $\mathrm{T}$, Mihashi $\mathrm{K}$, Cosentino LM, Morris-Natschke SL, Lee KH (2005) Anti-HIV benzylisoquinoline alkaloids and flavonoids from the leaves of Nelumbo nucifera, and structure - activity correlations with related alkaloids. Bioorg Med Chem, 13, 443-448

5. Shin MK, Han SH (2006) Effect of lotus (Nelumbo nucifera Gaertner) leaf powder on lipid concentrations in rats fed high fat diet rats. Korean J Food Culture, 21, 202-208

6. Lee KS, Kim MG, Lee KY (2006) Antioxidative activity of ethanol extract from lotus (Nelumbo nucifera) leaf. J Korean Soc Food Sci Nutr, 35, 182-186

7. Lee KS, Oh CS, Lee KY (2006) Antimicrobial effect of the fractions extracted from a lotus (Nelumbo nucifera) leaf. J Korean Soc Food Sci Nutr, 35, 219-223

8. Ko BS, Jun DW, Jang JS, Kim JH, Park SM (2006) Effect of Sasa Borealis and white lotus roots and leaves on insulin action and secretion in vitro. Korean J Food Sci Technol, 38, 114-120

9. Lee HK, Choi YM, Noh DO, Suh HJ (2005) Antioxidant effect of Korean traditional lotus liquor (Yunyupju). Int J Food Sci Technol, 40, 709-715

10. Kim DC, Kim DW, In MJ (2006) Preparation of lotus tea and its quality characteristics. J Korean Soc Appl Biol Chem, 49, 163-164

11. Han KY, Yoon SJ (2007) Quality characteristics of lotus leaf Jeolpyun during storage. J Korean Soc Food Sci Nutr, 36, 1604-1611

12. Yoon SJ (2007) Quality characteristics of Sulgitteok added with lotus leaf powder. Korean J Food Cookery Sci, 23, 433-442

13. Son KH, Park DY (2007) The quality characteristics of Sulgi prepared using different amounts of mulberry leaf powder and lotus leaf powder. Korean J Food Cookery Sci, 23, 977-986

14. Shin YJ (2007) Quality characteristics of fish paste containing lotus (Nelumbo nucifera) leaf powder. Koran J Food Cookery Sci, 23, 947-953

15. Baek WH (2008) Physicochemical and quality characteristics of noodles prepared with different concentate of lotus leaf powder and extract. Master thesis. Catholic University of Daegu, Daegu, Korea, p 1-45

16. MFDA (2002) Food Standard Codex. Ministry of Food and Drug Safety, Cheongwon, Korea, p 301

17. Folin O, Denis W (1912) On phosphotungsticphosphomolybdic compounds as color reagents. J Biol Chem, 12, 239-243

18. Blois MS (1958) Antioxidant determinations by the use of a stable free radical. Nature, 181, 1199-1200

19. Kato H, Lee IE, Chuyen NV, Kim SB, Hayase F (1987) 
Inhibition of nitrosamine formation by nondialyzable melanoidins. Agric Biol Chem, 51, 1333-1338

20. Bae JY, Park LY, Lee SH (2008) Effects of Salicornia herbacea L. powder on making wheat flour bread. J Korean Soc Food Sci Nutr, 37, 908-913

21. Chung HC, Lee JT, Kwon OJ (2004) Bread properties utilizing extracts of Ganoderma lucidum(GL). J Korean Soc Food Sci Nutr, 33, 1201-1205

22. Kim HY, Oh MS (2001) Comparisons of bread baking properties using domestic and imported flour and quality changes during storage. Korean J Dietary Culture, 16, 27-32

23. Kim EJ, Kim SM (1998) Bread properties utilizing extracts of pine needle according to preparation method. Korean J Food Sci Technol, 30, 542-547

24. Yu SK, Shin YM Kim MR (2006) Physicochemical and sensory characteristics of bread substituted with green barley. Chungnam J Human Ecology, 19, 64-71

25. Lee KS, Kwon YJ, Lee KY (2008) Analysis of chemical composition, vitamin, mineral and antioxidative effect of the lotus leaf. J Korean Soc Food Sci Nutr, 37, 1622-1626

26. Jo KH, Pae YR, Yang EJ, Park EJ, Ma SJ, Park YS, Chung DO, Jung ST (2006) Major constituents and bioactivities of tea products by various manufacturing. Korean J Food Preserv, 13, 596-602

27. Yang HC, Heo NC, Choi KC, Ahn YJ (2007) Nutritional composition of white-flowered and pink-flowered lotus in different parts. Korean J Food Sci Technol, 39, 14-19

28. Bing DJ, Chun SS (2013) Quality and consumer perception of white bread baked with Hallabong powder. J Korean Soc Food Sci Nutr, 42, 306-312

29. Yoon MH, Jo JE, Kim DM, Kim KH, Yook HS (2010) Quality characteristics of bread containing various levels of flowering cherry (Prunus serrulata L. var. spontanea Max. wils.) fruit powder. J Korea Soc Food Sci Nutr, 39, 1340-1345

30. Tae MH, Kim KH, Yook HS (2015) Quality characteristics of bread with burdock (Arctum lappa L.) powder. J Korean Soc Food Sci Nutr, 44, 1826-1831

31. Hong SY, Shin GM (2008) Quality characteristics of white pan bread with garlic powder. Korean J Food Nutr,
21, 485-491

32. Bae JH, Woo HS, Choi HJ, Choi C (2001) Qualities of bread added with Korean persimmon (Diospyros kaki L. folium) leaf powder. J Koean Soc Food Sci Nutr, 30, 882-887

33. Shittu TA, Raji AO, Sanni LO (2007) Bread from composite cassava-wheat flour: I. effect of baking time and temperature on some physical properties of bread loaf. Food Res Int, 40, 280-290

34. Jung DS, Lee FZ, Eun JB (2002) Quality properties of bread made of wheat flour and black rice flour. Korean J Food Sci Technol, 34, 232-237

35. Bae JH, Woo HS, Choi HJ, Choi C (2003) Quality characteristics of the white bread added with onion powder. Korean J Food Sci Technol, 35, 1124-1128

36. Pomeranz Y, Shogren MD, Finney KF, Bechtel DB (1977) Fiber in breadmaking-effects on functional properties. Cereal Chem, 54, 25-41

37. He H, Hoseney RC (1992) Effect of the quantity of wheat flour protein on bread loaf volume. Cereal Chem, 69, 17-19

38. Im MH (2011) Growth characteristics and major nutrient component of white lotus cultivated in Muan. Ph D. Thesis, Mokpo National University, Korea, p 50

39. Yook HS, Kim YH, Ahn HJ, Kim DH, Kim JO, Byun MW (2000) Rheological properties of wheat flour dough and qualities of bread prepared with dietary fiber purified from ascidian (Halocynthia roretz) tunic. Korean J Food Sci Technol, 32, 378-395

40. Park CH, Hur JM, Song KS, Park JC (2007) Phenolic compoungds from the leaves of Nelumbo nucifera showing DPPH radical scavenging effect. Kor J Pharmacogn, 38, 263-269

41. Yoon HS, Kim JW, Kim SH, Kim YG, Eom HJ (2014) Quality characteristics of bread added with Aronia powder (Aronia melanocarpa). J Korean Soc Food Sci Nutr, 43, 273-280

42. Park LY (2015) Effect of Houttuynia cordata Thumb. powder on the quality characteristics of bread. Korea J Food Sci Technol, 47, 75-80 